\title{
Breast Cancer Type 1 Susceptibility Protein
}

National Cancer Institute

\section{Source}

National Cancer Institute. Breast Cancer Type 1 Susceptibility Protein. NCI Thesaurus.

Code C17815.

Breast cancer type 1 susceptibility protein (1863 aa, $208 \mathrm{kDa}$ ) is encoded by the human BRCA1 gene. This protein plays a role in both the maintenance of DNA and the mediation of ubiquitin E3 ligase activity. 